\title{
July 1, 1835: What did the Caddo Believe they were Selling, and was the Price Paid Fair?
}

Jim Tiller

Unknown

Gang Gong

Follow this and additional works at: https://scholarworks.sfasu.edu/ita

Part of the American Material Culture Commons, Archaeological Anthropology Commons, Environmental Studies Commons, Other American Studies Commons, Other Arts and Humanities Commons, Other History of Art, Architecture, and Archaeology Commons, and the United States History Commons

Tell us how this article helped you.

This Article is brought to you for free and open access by the Center for Regional Heritage Research at SFA ScholarWorks. It has been accepted for inclusion in Index of Texas Archaeology: Open Access Gray Literature from the Lone Star State by an authorized editor of SFA ScholarWorks. For more information, please contact cdsscholarworks@sfasu.edu. 
July 1, 1835: What did the Caddo Believe they were Selling, and was the Price Paid Fair?

\section{Creative Commons License}

\section{(c) (1) \&}

This work is licensed under a Creative Commons Attribution-NonCommercial 4.0 International License 


\title{
JULY 1, 1835: \\ What did THE CADdo BelieVe THEY WERE SELling, AND WAS THE PRICE PaId FaIR?
}

\author{
Jim Tiller and Gang Gong
}

\begin{abstract}
Most Caddo scholars interested in the tribe's last years in Louisiana would probably agree that the above questions are largely settled business. The authors, both geographers, would tend to concur that a consensus has probably been reached on these questions; however, those with a desire to get at the truth of the matter might want to at least consider the array of archival documentation that paints a somewhat different picture of this aspect of the land cession. In the pages that follow, a case will be presented that, from the Caddo perspective of the mid-1830s, the tribe knew exactly what they intended to sell the United States, and that ultimately the per-acre price paid to them was greater than they proposed to the treaty negotiator. Certainly in hindsight the Caddo got the short end of the stick, but in terms of conditions on the ground at the time, period materials suggest that the deal made was fair, reasonable and clearly desired by both sides.
\end{abstract}

\section{Introduction $^{1}$}

From the time the Caddo first migrated into the Sodo Lakes area in the late 1700s until their final removal in early 1840, their experience was, in a general sense, little different from that of most native American groups whose lands lay in advance of the relentlessly expanding American frontier. The literature suggests that the Caddo arrived in the region from their former home higher up on Red River just prior to 1800, greatly weakened from disease and war with their neighbors. Sibley tells us that while they apparently found a degree of peace in their new home, their numbers continued to decline in the first few years as smallpox and measles took many more of the already weakened tribe.

Throughout the early decades of the 1800 s, a number of factors were at work which would ultimately lead to the decision of the Caddo to leave the region. Government sponsored factories and Indian agents, as well as the ever-present whiskey traders, offered a variety of highly desirable and otherwise unobtainable goods and services. In order to acquire these items, the tribe overhunted and thus depleted the surrounding environment, and, as the years passed, they were forced to move their seasonal hunts farther and farther from their Sodo Lakes homeland. Somewhat surprisingly, considering an already declining resource base, the Caddo willingly (to the extent they had a say in the matter), and sometimes even eagerly, permitted other tribes forced from their homes east of the Mississippi to settle among them - their chief asking in return for only a small annuity from the government. Early on the Caddo came to depend upon the work performed by Agency gunsmiths and blacksmiths. By the time these services were withdrawn in the mid-1830s, the tribe had grown so dependent upon them they were in danger of being unable to feed themselves. 
By the end of 1833, it was clear that time was running out for the Caddo in northwestern Louisiana and adjacent eastern Texas. In that year, long-time caddi Dehahuit died; the first steamboat made its way up Bayou Pierre to the Caddo Agency at Peach Orchard Bluff; and Henry Shreve cleared the Great Raft from the Red River up to Coates Bluff (near modern-day Shreveport). In adjacent Texas, where virtually all of the tribal villages were located, squatters were beginning to settle eastern Harrison County even as Mexican surveyors were staking claims as far east as the Red River. By late 1834, the Caddo appear to have had enough. In December of that year, Chief Tarshar and a number of his headmen sent a memorial to the President of the United States which stated in part

We have held a great Council and finally come to the sorrowful resolution of offering all our lands to you which lie within the boundary of the United States for sale at such price as we can agree on in Council, one with the other. ${ }^{2}$

On January 28, 1835, President Jackson referred the memorial to the Secretary of War for consideration. Jackson suggested that a commissioner be appointed to negotiate the treaty; that care be taken to not include any reservations in the treaty proper so that should the reservation(s) be rejected such would not void the treaty; and finally, he suggested that an appropriation be requested to cover the purchase of the tribal lands. ${ }^{3}$

\section{The Deal: An Introduction}

Much has been written about the land cession with authors describing and interpreting related events and often casting the government of the United States and its negotiating agent (and former Caddo Indian Agent) Jehiel Brooks as villains by suggesting they took advantage of the poor, weak Caddo, offering them a pittance in return for approximately 1,000,000 acres of land. Some, based on a selective reading of a number of period documents, have been quick to note that Brooks used his position to not only cheat the tribe of their "rightful due" in the negotiations, but also to defraud the United States of just over 18,000 acres on Rush Island, an area situated between the Red River and Bayou Pierre south of Shreveport boasting some of the most fertile agricultural land on Red River. ${ }^{4}$

The questions we will address in this article are two: (1) Just exactly what land did the Caddo intend to sell the United States (based on today's geography); and (2) Did, at $\$ 80,000$, the tribe receive a fair price for that land? Considering the circumstances on the ground in mid-1835, did the United States take advantage of the Indians, or could it have been the other way around? Is it possible that the tribe believed they were selling the United States a relatively small parcel of land, much of it low-lying, swampy, relatively useless and of little value to them, and that it was not until the United States began to push their surveys west toward Texas that the Caddo understood the magnitude of the error they had made?

\section{What Did the United States Believe it Was Purchasing?}

There can be little question the United States had a reasonably good idea of the boundaries (although not necessarily the total area) of the lands they were purchasing. In May 1825, at the request of George Gray,

Indian Agent on Red River during much of the 1820s, the United States established the boundaries of the Caddo Nation as follows

The line commencing at the mouth of Sulphur Fork thence meandering the old channel of Red River to its junction with the Cypress Bayou on the east and the Cypress Bayou on the southeast, Sulphur Fork on the west and the Spanish line on the southwest. Those lines are natural ones and generally understood as the boundary of the Caddo lands by both Indians and Whites. ${ }^{5}$ 
While the lines on the east (Red River), south (Cypress Bayou) and (actually) north (Sulphur Fork River) were natural and thus easily definable, the location of the as yet-to-be-established Mexican line was open to interpretation. In the mid-1830s, the United States was of the view that (William) Darby's Corner on the Sabine River (and the meridian/line northward from that point to the Red River) would serve as the basis for the establishment of the final boundary. The Mexican government believed the final boundary would fall in close proximity to (Gen. Manuel de Mier y) Terán's Corner on the Sabine and the meridian/line that extended north from that point to the Red River (Figure 1). ${ }^{6}$

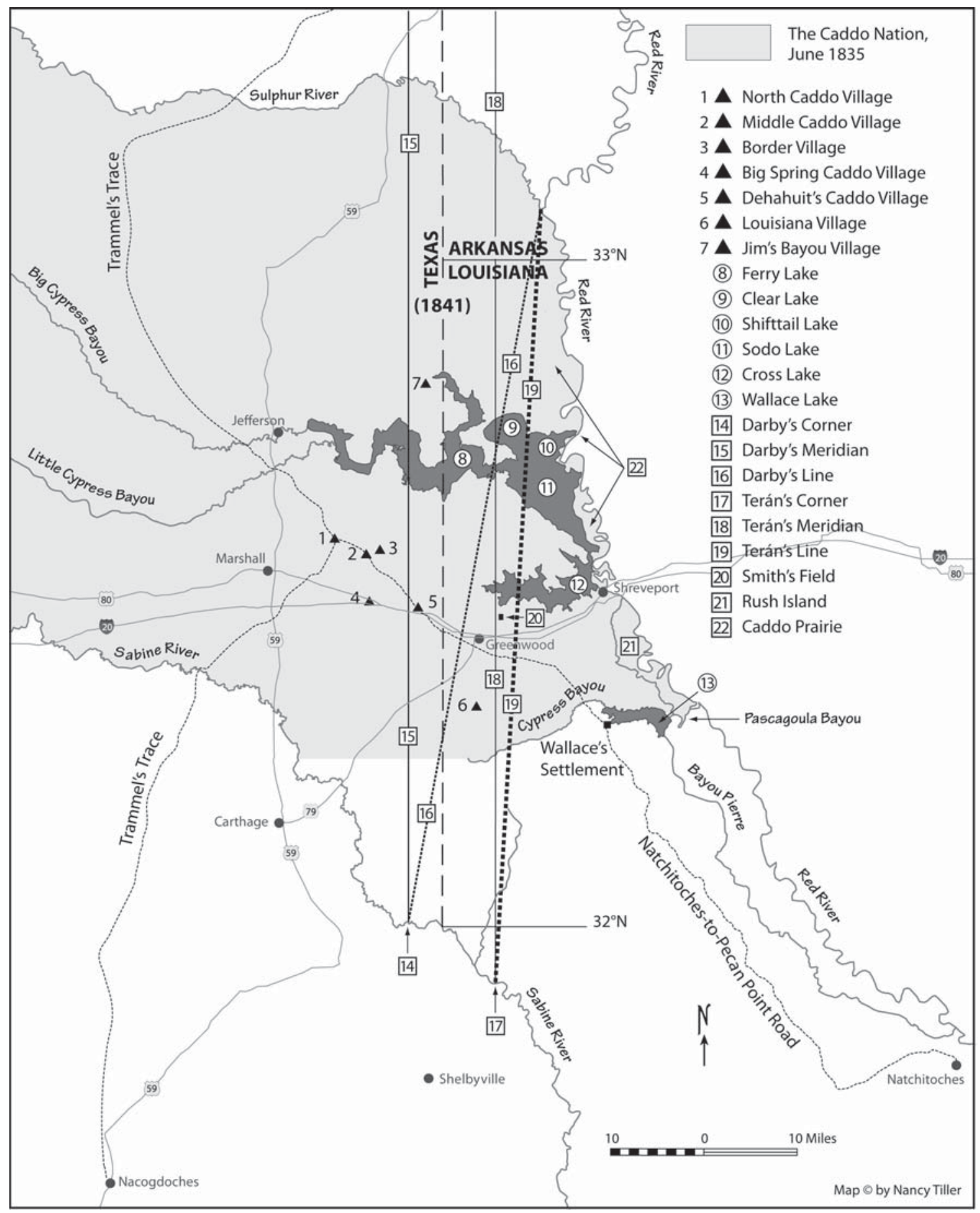

Figure 1. The Study Area. 
The fact an officially surveyed border with Mexico had yet to be determined by no means deterred President Jackson from authorizing the appointment of a commissioner to negotiate with the Caddo for their lands. Doubtless his concern was less the precise quantity of land to be acquired, and more the removal of the tribe from northwestern Louisiana in order that the area might be opened for settlement.

\section{What Did the Caddo Believe They Were Selling?}

Like the United States, the Caddo accepted the 1825 boundaries as suggested by Gray and agreed to by the United States. In the 1834 memorial, they defined the lands they wished to sell as

bounded on one side by the Red River, on another side by Bayou Pascagoula, Bayou and Lake Wallace and the Bayou Cypress; and the other side by Texas. ${ }^{7}$

Unlike the Americans, who put their faith in Darby's Corner (and Line), the Caddo believed the final boundary would fall near the Line defined by Gen. Terán in 1828 (Terán's Line). ${ }^{8}$

\section{The Darby and Terán Lines}

Before we begin, let us take a moment to consider the nature of the two meridians associated with the Darby and Terán's Corners respectively. Meridians are a part of the earth's geographic grid and as such they run due north and south (and measure angles of longitude east or west of the Prime Meridian). Clearly the "meridians" associated with both the Darby and Terán Lines angle off to the northeast from points on the Sabine. What is this all about?

Both Darby and Terán devoted considerable effort in their attempts to locate their Corners on the Sabine. Once accomplished, all that would been have necessary to establish the international border between the United States and Spain (and in time Mexico and later Texas) would be to extend by survey a meridian due north from that point to the Red River as called for in the Adams-Onís Treaty. In 1835, this would not have been as easy to do as it may sound. Few Whites had traversed the region other than by way of the meandering, raftfilled Red River or along the Natchitoches-to-Pecan Point Road. Because the area had not been systematically surveyed, true direction was very difficult if not impossible to establish over great distances. In addition to lack of survey, annual spring floods and more semi-permanent inundations associated with the relentless advance of the Great Raft upstream created an ever-shifting landscape in the lower-lying areas and especially along and adjacent to the region's larger streams lakes. What one year was an open prairie might the next year have morphed into a vast lake. For instance, for the first time in living memory there were significant floods in the Caddo Prairie region north of present-day Shreveport in 1826, 1828 and 1830-the result of the advance of the Great Raft to points north or Shreveport. These floodwaters, which covered the Prairies to a depth of four feet, were the primary cause of the abandonment of the Caddo Agency in the late 1820s. ${ }^{9}$

Because of the nature of the terrain and a general lack of knowledge concerning direction between important landmarks in the Sodo Lakes region, those on both sides of the international boundary-to-be appear to have referenced the well-known mouth of the Sulphur Fork River as the approximate location where they believed their respective Lines would terminate on Red River. The result, we can readily see today, was a pair of "meridians" (the Darby and Terán Lines) whose course was slightly to the east of due north (see again Figure 1). 


\section{The Caddo View of the International Boundary}

There can be no question the Caddo believed Terán's Line to have been the western boundary of the lands they were prepared to sell the United States. In his summation to the New Orleans District Court jury in United States vs. Jehiel Brooks, et al., Brooks described the location of the Line as understood by area residents, both White and Indian alike. He noted that in the fall of 1828 he

met a small detachment of Mexican troops, with an officer, who represented himself as General Terán, of the Mexican Army. In reply to an inquiry of mine he said that he had been ascertaining, as near as practicable, where the line ran from the Sabine to the Red river, dividing Mexico from the United States. That he had done this by direction of his government, and was then on his return to Texas: That there was nothing official intended in the act, nor was he well assured of the accuracy of his instruments, and calculations; but he thought they might approximate near enough to form something like a general guide to all the purposes of a wilderness, etc. I ascertained from the Indians afterwards where this line ran. It passed close to the head of Cross lake, leaving all the major Indian villages on the Texas side of it, ${ }^{10}$ and struck Red river some distance below [authors' emphasis] the Caddo prairies. I also learned that the General had determined the intersecting point on the Sabine of the $32^{\circ} \mathrm{n}$. Latt. some distance east and south of Darby's calculation; and that he did not attempt to run by his compass connecting from sight tree to sight tree. And it was generally known [at least by Whites] that his line was too far east of a due north course from Darby's corner as it was called, to be thought correct. ${ }^{11}$

It is significant that in the well-known Grappe land dispute, ${ }^{12}$ which pitted Brooks against a number of pioneer Rush Island settlers, Brooks, along with Joseph Valentin, Sylvestre Poissot and Manuel Laffitte (all of whom provided testimony against Brooks), associated Terán's Line with the lands sold by the Caddo. ${ }^{13}$ While the tribe believed that upon final survey the United States-Mexican (Texas) border would be found to lie in close proximity to what was generally known as Terán's Line, Brooks (and the United States) could not be expected to conclude a treaty based upon what one side thought. Although Brooks initially believed the Caddo understood Terán's Line was only an approximation, he noted in his summation that he

had supposed that the Indians also were satisfied of its inaccuracy until at the treaty, when they adverted to that line as bounding the United States west. I then told them that, whether Terán's line should prove correct or not, the United States did not recognize it, and therefore, a new line would have to be run, before the extent of their cession could be ascertained. ${ }^{14}$

Despite the fact the Caddo believed Terán's Line to have been the western boundary of Louisiana and thus the western boundary of the lands they were willing to convey to the United States, by the time they arrived on the treaty grounds and were made aware of the goods that would be given to them upon the successful conclusion of negotiations, ${ }^{15}$ it appears they, in their impoverished condition, decided to take the goods and make the best deal they could and, like the Americans (whose information regarding the western boundary was actually little better than that of the Caddo), await the running of the final boundary to determine what would be the eastern border of their lands in Texas.

\section{Some Things to Think About}

In the twenty-first century, it is easy in hindsight to make the case that the United States took advantage of the Caddo in the purchase of their northwestern Louisiana homeland for a mere $\$ 80,000$. Today, one good Haynesville shale gas well, a little timber and a few cows can easily produce as much in a single year-and one can only guess at what the newly discovered oil formation below the shale will yield area landowners in the years ahead. 
However, if one is to truly understand the nature of the Caddo land cession, it is necessary to examine conditions on the ground at the time of the sale which possibly could have influenced the nature of the deal struck. If we suppose for the moment the Caddo ceded the United States 1,000,000 acres as some have suggested, ${ }^{16}$ the average cost per acre would have been approximately $\$ .08$, a paltry sum in today's market surely—but would it have been in mid-1830s frontier Louisiana? The reader will recall that President Jefferson acquired the Louisiana Purchase for approximately $\$ .03$ an acre. We know the United States under Jackson, taking the long view, was inclined to move Indian populations ever-westward in order to make room for White settlement, and this doubtless was a significant factor in the decision by the United States to purchase the Caddo lands. Certainly by the late 1830s when the General Land Office opened the Caddo purchase for sale, the going rate for government land was $\$ 1.25$ per acre ${ }^{17}$-but the treaty was signed in 1835 . At that time there were virtually no White settlers to be found within the Caddo cession. When Henry Shreve cleared the Red River of the Great Raft to near Shreveport in late 1833, there was no Shreveport (1836). And one should not forget that Shreve's work notwithstanding, the Raft was reclaiming sections of the river even as the ink was drying on the treaty. In fact, it would be 1839 before Shreve was able to completely clear the Raft from the Red River for the first time.

Too, do those with an interest in this topic completely ignore previous efforts to place a mid-1830s market value on the Caddo purchase lands? While the ceded territory possessed virtually no history of land transactions prior to 1835 , we know that at the time a bushel of corn could bring $\$ 1.25$, and it took 100 acres to purchase a good horse. In adjacent eastern Harrison (then Shelby) County, a person who immigrated to Texas prior to independence could secure at no cost a league and a labor of land (approximately 4428 acres); the immigrant was only required to pay government fees of $\$ 101.40$ to close the process, a per acre cost of approximately $\$ .02 .{ }^{18}$ In 1835 , land in northwestern Louisiana and adjacent Texas was plentiful and it was cheap.

In the 1830s, the land on either side of present-day US Highway 1 between Shreveport and Wallace Lake was a part of what was known as Rush Island. Today this area boasts some of the finest farmland in Louisiana outside that found on the Mississippi River floodplain; yet as late as 1884, almost a full 50 years after the Caddo treaty, over half of Rush Island proper was heavily timbered backswamp. ${ }^{19}$ How does one put a price on lands up and down the Red River floodplain which for many, many decades prior to (and after) the cession were little more than swamplands? And if the rich alluvial soils of Rush Island, which certainly would have attracted prosperous planters with their legions of slaves, were slow to develop, how much could the inherently less productive lands in the western portions of the Caddo cession (the uplands) have been worth to small farmers in 1835 ?

Finally, is there any evidence regarding the value the Caddo themselves placed on the lands they intended to sell the United States? Most of the literature deals with the White side of the price equation, yet it seems unreasonable to believe that the Caddo would have taken anything on the order of $\$ .08$ an acre for their land had they placed any significant value on it.

In the following paragraphs, we will address the boundaries described and understood by each side of the negotiation. In the mid-1830s, the Red River, the mouth of the Sulphur Fork, and the Caddo south border (Cypress Bayou) were largely natural boundaries whose general locations were understood by all. Today, these locations can be very precisely located. Of course the streams have shifted slightly over the intervening 175 years, but for the purposes of our discussion, such changes will be deemed minor. Other boundaries such as the Darby and Terán Lines and those of various Public Land Survey townships, while man-made, were known in a general sense to most in the region. By using the various boundaries discussed by the negotiating parties, it is possible to derive closely approximated land areas/acreages. These calculated acreages will form the basis for much of the discussion to follow. 
What Was the Approximate Acreage

the Caddo Thought They Were Selling to the United States?

As we have noted, is difficult to understand the basis for the 1,000,000 acre figure so often associated with the Caddo cession. If one takes Brooks, Valentin, Poissot and Laffitte at their word that Terán's Line was understood by the Caddo to have been the boundary of the land they intended to sell; that this line passed near the Smith (Smyth) improvement in Sections 7 and 8, T17N, R15W near the head of Cross Lake; and that the Line struck the Red River at the mouth of Sulphur Fork, then the land the Caddo believed they had sold the United States totaled some 238,500 acres (Figure 2).

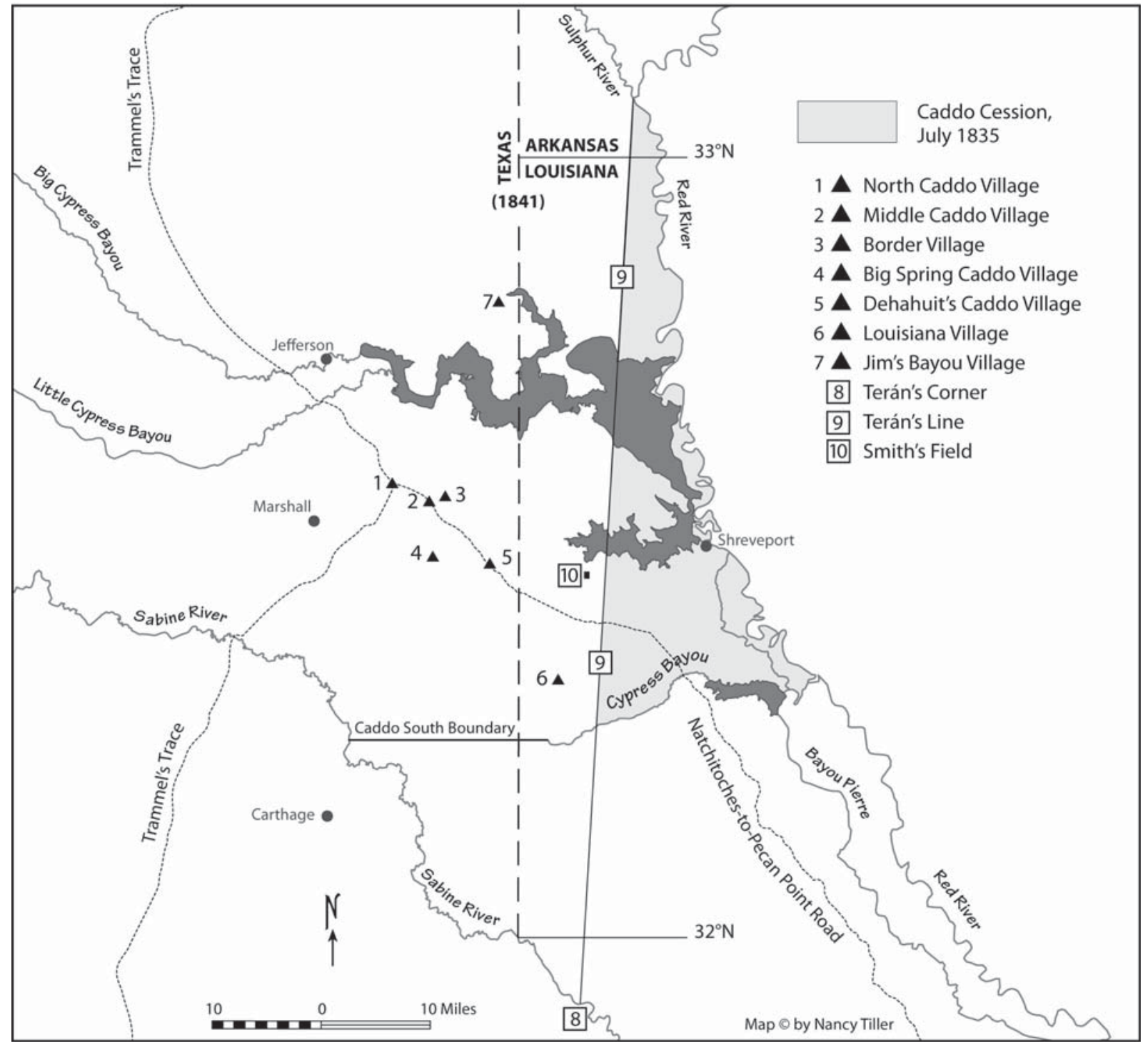

Figure 2. The Caddo Land Cession, 1835. 
Of course, it is important to remember that the Caddo, although well aware they would have to await an official survey to determine the actual Louisiana-Texas boundary and thus the western border of their land cession, almost surely did not believe they were selling land westward to anywhere near what is today's TexasLouisiana border. While believing Terán's Line to have been the international boundary, they signed the treaty with the full knowledge that the true extent of the land they were selling could not, as Brooks told them, finally be determined

till the Mexican line was run and the lands measured; that [he, Brooks] wished to fix on a round sum for their whole country on this side of the Mexican line, let the quantity of land be small or great ${ }^{20}$

It was a gamble on the part of the Caddo; but was one they probably understood, based on their considerable knowledge of the Sodo Lakes region, would be settled in their favor.

\section{What Was the Approximate Acreage the Caddo in Fact Sold to the United States?}

The acceptance of Terán's Line as the international boundary by all concerned could have been the end of it; however, the signing of the treaty did not resolve the boundary issue as regards the United States. In January 1837, with the Caddo continuing to occupy their villages just west of Terán's Line, the United States began surveying out R16W. ${ }^{21}$ Beginning on the Sabine, American surveyors reached the Louisiana Caddo village in March. ${ }^{22}$ As required by the 1835 treaty, the tribe had abandoned the village, and there is evidence that by late 1836 or early 1837 they had removed all their villages east of the western boundary of R16W to Texas. ${ }^{23}$ By late May 1837, the Americans had completed work in the townships south of Cross Lake as well as those in R14W east of the Red River (Figure 3). The reader will note that the western boundary of T17N, R16W24 lay barely two miles east of Dehahuit's village. The Caddo, who at the time still resided in their villages west of R16W, as well as area Whites, knew that once the anticipated surveys in R17W began Dehahuit's village would fall within the bounds of the United States and, as required by the 1835 treaty, the village would have to be abandoned. In December 1837, the United States completed its survey of T21N, R16W-the first survey in R16W to be finished north of the Sodo Lakes complex.

At this point it was clear that neither the Darby nor Terán Line terminated at the confluence of the Sulphur Fork and Red Rivers, and that the international boundary, once formally surveyed, would pass a considerable distance west of the confluence of the two rivers.

But the United States was not done yet. In April 1837, Washington authorized the survey of an additional 6-mile wide range (R17W) in what they believed to be northwestern Louisiana. ${ }^{25}$ By the time the surveys in R16W and R17W were nearing completion in late spring 1838, ${ }^{26}$ the Caddo had been forced from their eastern Harrison County villages to the western prairies of Texas. Although these surveys had no direct impact on the tribe, it is interesting to note that their completion resulted in Caddo "losing" to the United States an additional 656,000 acres in southern Arkansas, northwestern Louisiana and eastern Texas south of the Sulphur Fork. ${ }^{27}$ Terán's Line of 1835 (keep in mind that it angled slightly southwest to northeast), which the tribe had placed so much faith in, was situated approximately 9 miles due west of Shreveport. By the summer of 1838, the new American border (at least for administrative purposes) lay 6.5 miles west of the current Texas-Louisiana boundary, or some 24 miles west of Shreveport. ${ }^{28}$ 


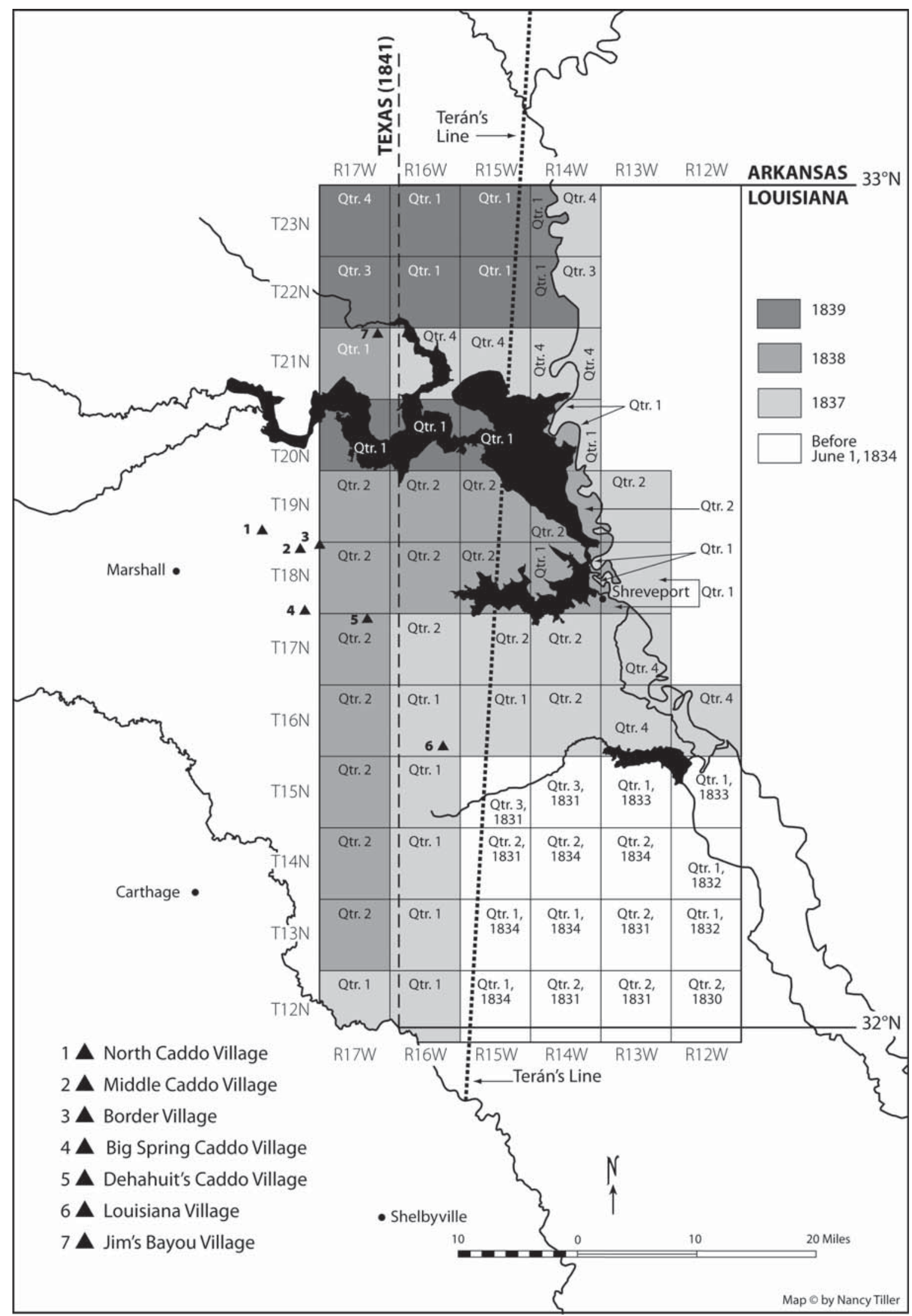

Figure 3. American Surveys in Northwestern Louisiana. 
The reader is again reminded that our concern in this paper is not what the United States ultimately gained as a result of the Caddo cession. After all, in July 1835, neither side could have guessed the final boundary would have taken the path that it did, and of course neither side had any firm knowledge of the area/acreage involved. Our focus in this paper is on what the Caddo thought they were selling the United States based upon the acreage contained within the bounding lines alone. Clearly the tribe never intended to sell the United States $1,000,000$ acres - they simply did not possess such an area within the bounds of what was then understood to be Louisiana. Nor did they intend to cede the Americans the approximately 600,000 acres east of the presentday Texas-Louisiana border south of the Sulphur Fork. Such a line did not exist in 1835.

Based on the Caddo perception of Terán's Line as the approximate location of the United States-Mexican border, there is a case to be made that at the time of the treaty, the tribe believed, based on today's geography, they were only selling the United States some 238,500 acres, all land far to the east of their villages. However, just as Brooks had predicted, once the Americans completed their surveys of R16W and R17W (and in so they created a "temporary" international border), the United States had absorbed a total of almost 895,000 acres in northwestern Louisiana, southern Arkansas and eastern Texas south of the Sulphur Fork, including at least three of the larger Caddo villages in the region.

\section{Was a Fair Price Paid for the Land Sold?}

It is difficult to judge whether $\$ 80,000$ was a fair price for the Caddo cession east of Terán's Line without some knowledge of the situation the tribe found itself in as well as other conditions at the time which may have influenced the value both the Indians and the United States placed on the land. At the very least one should ask (1) What was the condition of the tribe in the period leading up to the sale; (2) Is there any evidence regarding a value the Caddo themselves placed upon the land; (3) Of what value might the lands have been to the United States; and (4) Is there any evidence in the record that the Caddo felt they had been cheated by the terms of the treaty?

\section{The Condition of the Caddo at the Time of the Sale}

The Caddo doubtless had good reason to want to sell a portion of their lands. We know from the 1834 memorial to the President the tribe no longer had access to the services of the gunsmith or blacksmith previously provided by the United States, ${ }^{29}$ and, with the removal of their agent, ${ }^{30}$ there was concern that White settlers no longer subject to the authority of the Indian agent would soon begin occupying their tribal lands. ${ }^{31}$ Too, it is clear that the tribe hoped to sell their land to the United States in order that they might "obtain some relief from our pressing necessities."32

Col. James B. Many, in his January 1835 report to the Office of Indian Affairs, observed that the Caddo were

a poor and indolent people who will not work and, as the game is becoming very scarce, they plunder the inhabitants of their cattle and hogs to a great extent of which the citizens complain much. ${ }^{33}$

Col. Many correctly believed the Caddo settlements would, once the final boundary was determined, be found to lie on the Mexican side of the line; ${ }^{34}$ that many Caddo had already crossed the line to settle in Mexico (actually they had simply returned to their traditional villages in eastern Harrison County); that they at the time of his report possessed a Mexican grant of land in that country; and that they

are more attached to the Spanish than to the Americans and that the only thing that has kept them from going over to the Spaniards for some time past was the few presents they have received and the work that has been done for them by the gunsmith furnished by the United States. ${ }^{35}$ 
Tsauninot, one of the under-chiefs, noted in a June 26 speech prior to the signing of the July 1, 1835 treaty that the Caddo were

in great want ... [that the President in treating for their lands] would supply us with things of much more value to us than these lands, which yield no game. [that Tarshar, the head chief, was out on a hunting party but had told Tsauninot that] if you [Commissioner Brooks] came before his return, to say for him that he gave his consent to whatever we might agree to, and would never hereafter make any objection to its fulfillment. [That the Caddo believed the President would] deal justly with us. ${ }^{36}$

In his June 27 treaty ground speech, Tsauninot noted that Brooks

had brought a great many rifles, and powder and lead in abundance, axes, tomahawks, knives, and flints, blankets, cloths, and calicoes, and beads and shawls, and, indeed every thing we are so much in want of; all of which you would give to us, at once, if we would deliver up this country to the White people. They hung down their heads and were sorrowful. Then our head chief, Tarshar, rose and said:

My Children: For what do you mourn? Are you not starving in the midst of this land? And do you not travel far from it in quest of food? The game we live on is going further off, and the White man is coming near to us; and is not our condition getting worse daily? Then why lament for the loss of that which yields us nothing but misery? Let us be wise, then, and get all we can for it, and not wait till the White man steals it away, little by little, and then gives us nothing. This is my advice; if you think it good, rise up and dance the corn dance, but if bad, let not the drum be beaten to-night, and we will depart for our homes to-morrow. ${ }^{37}$

The minutes of this meeting noted that after a short pause, the Caddo "all sprang to their feet with cries of satisfaction, and proceeded to perform the [corn] dance with unusual animation." ${ }^{38}$ Brooks, in summing up events as they had transpired at the treaty ground, wrote in his final treaty journal entry that the

Indians, generally, expressed great satisfaction with everything they received, and with the whole proceeding, from the beginning to the ending. None went away dissatisfied. ${ }^{39}$

\section{Caddo Comments Regarding the Value of the Lands Sold}

At the same June 27 meeting noted above, Brooks asked the tribe for the price they wished for their land. Tsauninot replied

that the Caddoes had been advised to ask two hundred dollars a mile; one hundred in money, and the other in goods. ${ }^{40}$

As far as can be determined from the record, this is the only evidence we have of what the tribe believed their lands were worth at the time of the treaty. Based on a price of $\$ 200$ per mile ( $\$ .31$ per acre) and the now-known extent of their lands east of Terán's Line (238,500 acres), the Caddo initially proposed to sell Brooks their land for a total of approximately $\$ 74,500$.

Between 1835 when the treaty was signed and 1840 when the last of the tribe left the region for Indian Territory, Caddo officials had many opportunities to address the Indian Office/War Department and other government officials regarding the payment of their annual annuity. There is not a single instance in these records in which the Caddo expressed the least dissatisfaction with the actual dollar amount paid them for their lands. ${ }^{41}$ In addition to these various memorials and petitions, there are a number of letters from merchants, Army officers and government agents referencing direct contact they had with the Caddo. Once again, there is not a single instance in any of the documents that suggest the Caddo had any reservations as regards the dollar amount paid them for their lands. Based on these materials, it is difficult to make a case (other than in hindsight) that the Caddo did not believe they had received a fair price for their lands in the 1835 treaty. ${ }^{42}$ 
In fact, just the opposite appears to be the case. The lack of documentary evidence to the contrary suggests that at the time the treaty was signed, the Caddo believed they had been fairly treated with respect to the price paid for their land. Considering their impoverished condition, the loss of the Indian agency and its services; the prospect of ever-encroaching White settlers onto their lands; the fact the area ceded yielded little in the way of game and thus was of little value to them; the perception on their part that their villages all lay in Texas and thus would not be impacted by the sale; the much-needed goods offered in trade for the land; and the willingness in 1835 of the Mexican government to continue to provide them a home-the question that more readily comes to mind is, "Exactly what would have been the advantages to the Caddo, in that time and place, of holding on to their Louisiana homeland?"

\section{The Nature of the Land Sold: Was the Price Fair?}

Any land transaction such as that which took place between the Caddo Nation and the United States surely involved some degree of negotiation. As noted above, the Caddo, when asked by Brooks for the price they would take for the land they believed they were selling (238,500 acres), responded with a figure of $\$ 200$ per mile (the equivalent of $\$ .31$ cents per acre) or a total asking price of approximately $\$ 74,500$, a figure very close to the final price of $\$ 80,000$. The reader is again reminded that neither the Caddo nor Brooks had knowledge of the actual acreage being conveyed-the negotiations and final agreement were based solely on the boundaries of the land ceded as understood by both parties at the time. Interestingly, this price was considerably above what the Indians seemingly had been prepared to sell their Louisiana lands for in the months leading up to the treaty. The much-referenced House Report 1035 offers testimony suggesting the Caddo ascribed relatively little value to their Louisiana lands. In his December 1840 deposition in the Grappe matter, Joseph Valentin, swore that

these [Caddo] lands could have been purchased for twelve hundred dollars [\$.005 per acre]; [he, Valentin] knows that the head chief offered to his father, Andre Valentin, to relinquish all the Indian land to him for his stock of goods, which was then worth from a thousand to twelve hundred dollars. This chief was Tarshar, and the offer was made about five or six months before the treaty, which was then in contemplation. $^{43}$

Cesair Laffitte swore in the same Grappe controversy that

the Indians would have sold their territory for the sum of two or three-thousand dollars at the most [\$.008 to $\$ .01$ per acre]; perhaps for less than either named sum. ${ }^{44}$

Brooks well understood that the area ceded contained a great deal of land that the United States would probably find very difficult to dispose of though their public sales. As the long-time Caddo Agent, he may even have been aware of comments similar to those ascribed to the Caddo by Valentin and Laffitte.

Before we can judge whether or not the price finally agreed upon was reasonably fair to the Caddo, we need to examine factors that Brooks almost surely took into account before responding with the offer of the United States. In considering the paragraphs that follow, the reader is once again reminded that our discussion is focused on conditions in 1835 at the time of the land cession.

To begin, in 1835 there were virtually no economically viable resources to be had within the Caddo purchase aside from those associated with first wave agriculture colonization. While almost totally covered by vast forests of both hard and soft woods, the closest market for such products was New Orleans, and the Red River had not yet been reliably opened for navigation. As noted by the Indian Claims Commission in 1960 
The evidence points substantially to the fact that there was no market in 1836 or in the near future for the timber within the subject area [the Caddo purchase], and a hypothetical purchaser well acquainted with all the facts would give little or no value for timber in buying lands with[in] the subject area. ${ }^{45}$

While potentially very fertile lands were to be found adjacent to the Red River, much of the floodplain acreage was subject to extended periods of flooding thus diminishing their value. Conditions were such in the uplands that as late as 1907 an agricultural report presented to the Indian Claims Commission estimated that

out of a total of 528,000 acres of land in Caddo Parish, only 180,000 are improved farm lands. This leaves about $66 \%$ of the parish in uncleared lands as of this late date. ${ }^{46}$

In summing up the agricultural prospects of the region in the mid-1830s, the same 1907 report noted that

Considering the topographical, soil and climatic conditions relative to the ceded area, the highest and best use for these lands in 1836 [was] for agricultural purposes incident to subsistence homesteading. When the inadequate transportation facilities both overland and by water are coupled with the lack of adequate means of flood control, there is no immediate prospect of any extended commercial use of the Caddo lands as of the date of valuation either by the cultivation of cotton or the cutting of timber. Any prospect of such a use would be projected too far into the future to be an important factor in influencing the then 1836 market value of this area. ${ }^{47}$

Finally, it should be pointed out that a substantial portion of the Caddo purchase was actually comprised of permanent waterbodies (lakes, streams, swamps, cane breaks, and the like). Within the Caddo cession some 47,500 acres were covered by the Sodo Lakes complex and Wallace Lake as depicted on the late 1830s United States survey plats. If we add to this the swamp and overflowed lands (which probably totaled at least 38,000 acres at the time of purchase) (Figure 4), ${ }^{48}$ the quantity of land that could have been cultivated in 1835 east of Terán's Line was approximately 153,000 acres. In other words, of the 238,500 acres purchased in 1835, only two-thirds were suitable for the relatively primitive agriculture practiced at the time.

While there were doubtless a number of other factors that went into Brooks' decision as regards the dollar figure he developed to respond to the Caddo offer, if we just consider those examined above, and assume for the purposes of discussion that Brooks used Terán's Line as it was then understood as the western boundary of the lands to be purchased, then the $\$ 80,000$ purchase price bought either

- a total area of 238,500 acres (average per-acre price paid of $\$ .33$ )

or

- $\quad 153,000$ acres of arable (ca. 1835) land (average per-acre price paid of \$.52)

Either way, the average cost per acre was far more generous than later writers have been willing to attribute to Brooks and the United States. ${ }^{49}$ 


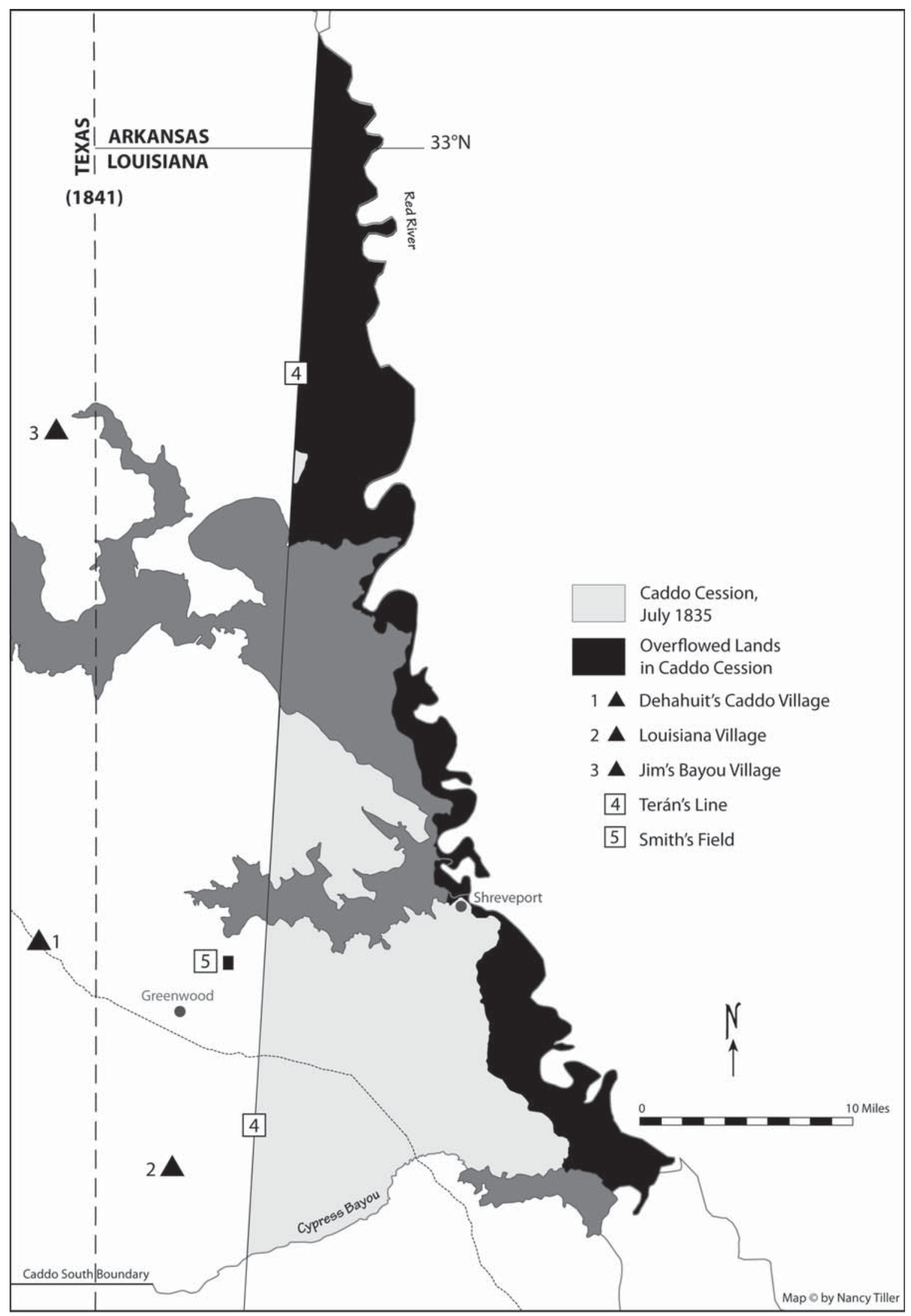

Figure 4. Overflowed Lands within the Caddo Cession. 


\section{Summary Comments}

Based on the evidence found in period materials and presented above, it is difficult to see how one can argue that the Caddo were cheated out of their northwestern Louisiana lands. To begin, writers who insist upon identifying the Caddo lands sold as lying east of the modern Texas-Louisiana boundary, or worse, that the lands sold extended for great distances into surrounding states (the segment of Arkansas south of the Sulphur Fork confluence excepted) are doing a great disservice to the discussion considering the fact that both the United States and the Caddo agreed on the boundaries of the lands being purchased/sold. The evidence is clear; the Caddo believed Terán's Line served as the western boundary of the lands they intended to sell. Contrary to what secondary sources have to say on the matter of the location of period Caddo villages, all of the larger 1830s-era settlements lay to the west of this line. There is no question the 238,500-acre region east of Terán's Line the Caddo proposed to sell was largely devoid of game and consequently of little value to the tribe. Valentin and Laffitte both indicated that these lands could have been purchased for less than $\$ 3000$-and Valentin swore this figure had been advanced by none other than Tarshar, the head chief of the Caddo.

By the time they arrived on the treaty grounds, the Caddo had been advised to take no less than $\$ 200$ per mile. Brooks refused this figure, not because it was deemed too high, but because there was at the time no means to determine how many square miles the lands to be ceded actually contained - the range and township surveys would not take place across much of the region for another three to four years. In fact, if the United States had taken the tribe up on the $\$ 200$ per mile figure (and the land area the Caddo thought they were selling east of Terán's Line), we know today the Caddo would have realized some $\$ 5500$ less than they actually received as a result of the treaty negotiations!

To those who denigrate the actions of Brooks in the treaty matter regarding the price offered, would it not have been reasonable to have expected our 1835 treaty negotiator to strike the best bargain possible for the United States (while at the same time not taking too great advantage of the situation the hapless Caddo found themselves in)? Clearly the lands purchased did not at the time hold a great deal of immediate value to the United States, and, as the record shows, this situation did not materially change for a number of decades.

Based on the totality of the evidence presented, it seems more than fair to suggest that the Caddo initially had a relatively clear idea of the boundaries of the land they wished to sell; that once it became clear the means were not available to strike a bargain based upon area/acreage alone (the $\$ 200$ per mile offer), they settled for the desperately needed goods and placed their hopes on their belief that Terán's Line and the yet-tobe-finalized United States-Mexican border lay in close proximity to each other-a huge mistake on their part, although in 1835 it is not at all clear the information the United States possessed on this matter was any more accurate. The literature contains many comments regarding the supposed location of the boundary between the United States and Mexico (later Texas), and, even as late as 1837, some placed the north boundary between the two on the Red River in the Caddo Prairies just north of Shreveport.

It is the contention of the authors that the Caddo believed they were selling the United States a very small part of their Sodo Lakes homeland, and that in fact much of what they intended to sell was low-lying, swampy, relatively useless and of little value to them. They doubtless received more at the time of the signing than they expected, and all indications suggest they were pleased with the dollar amount negotiated. As noted at the beginning of this article, it was not until the United States began to push their surveys west toward Texas that the Caddo understood the magnitude of the error they had made. 


\section{Endnotes}

1. This section adapted from Tiller, Jim. Before the Line. Vol. III, Caddo Indians: The Final Years. Working manuscript.

2. Chiefs and Headmen of the Caddo Nation. Memorial to the President of the United States. No date. National Archives and Records Administration. Letters Received by the Office of Indian Affairs, 1824-1881. Roll 31, Caddo Agency (same as Tiller, Jim. Before the Line. Vol. II, Letters from the Red River, 1809-1842. Huntsville, TX: The START Group, 2012. Item 566); 27th Cong., 2nd sess. House Report 1035. p. 99.

3. Jackson, Andrew. Letter to Lewis Cass, Secretary of War. January 28, 1835. National Archives and Records Administration. Letters Received by the Office of Indian Affairs, 1824-1881. Roll 31, Caddo Agency (same as Tiller, Jim. Before the Line. Vol. II, Letters from the Red River, 1809-1842. Huntsville, TX: The START Group, 2012. Items 565/567); 27th Cong., 2nd sess. House Report 1035. p. 100. In the instructions provided to Brooks by the government, he was not permitted to offer more than $\$ 100,000$ to the Caddo for their lands. ${ }^{3.1}$

3.1. Cass, Lewis. Letter to Jehiel Brooks. March 25, 1835. National Archives and Records Administration. Letters Sent by the Office of Indian Affairs, 1824-1881. Reel 15. Letter of Instructions for negotiating a treaty of land cession with the Caddo Indians.

4. These views doubtless had their origins in a number of 1840s-era government documents (most notably 27th Cong., 2nd sess. House Report 1035) that ultimately led to the "Joint Resolution to Institute Proceedings to Ascertain Title to Rush Island Ceded in the Caddo Treaty" found in House Report 1035. These documents set in motion legal efforts on the part of the United States to attempt to reclaim the 18,000-acre Grappe reservation from Brooks. Tried in the 5th Circuit Court, District of Louisiana, the jury reached a decision in favor of Brooks in just 10 minutes. ${ }^{4.1}$ Appealed by the government to the United States Supreme Court, Brooks again prevailed. ${ }^{4.2}$

It should be noted that Brooks was involved in a number of lawsuits related to the Grappe reservation, two of which ultimately reached the United States Supreme Court. While United States vs. Jehiel Brooks, et al. was settled in Brooks' favor, the second case, Jehiel Brooks, Plaintiff in Error vs. Samuel Norris, was not. The decision of the Louisiana Supreme Court in Brooks vs. Norris in favor of Norris prompted Brooks to appeal that case to the United States Supreme Court. ${ }^{4.3}$ The appeal was rejected by the Court, not on the merits of the case, but rather due to the fact that the writ of error was filed too late to meet the five year requirement for such filings.

4.1. The United States vs. Jehiel Brooks, et al., United States Circuit Court for the Eastern District of Louisiana. Case 1459 (entry ELA121, General Cases, 1837-1911). National Archives and Records Administration, Southwest Region. Fort Worth, Texas; Lewis, Thomas H. Letter to Jehiel Brooks. May 5, 1848. Box 2, Folder 2, Item 1, The Brooks-Queen Family Collection. The American Catholic History Research Center and University Archives. The Catholic University of America. Washington, D.C. p. 1 (see URL, http://www.aladin0.wrlc.org/gsdl/collect/brooks/brooks.shtml). In his letter, Lewis observed that "the question of fraud has met a glorious negative by the jury."

4.2. United States vs. Jehiel Brooks, et al., 51 U. S. 442 (1850). 


\section{Endnotes (cont.)}

4.3. Jehiel Brooks, Plaintiff in Error vs. Samuel Norris, 52 U.S. 204 (1850).

5. Gray, George. Letters to James Barbour, Secretary of War. May 26, 1825 and September 30, 1825. National Archives and Records Administration. Letters Received by the Office of Indian Affairs, 1824-1881. Roll 727, Red River Agency (same as Tiller, Jim. Before the Line. Vol. II, Letters from the Red River, 1809-1842. Huntsville, TX: The START Group, 2012. Items 313, 320); 27th Cong., 2nd sess. House Report 1035. p. 107.

6. In 1811 the United States unofficially and arbitrarily defined the northwestern boundary of Louisiana as beginning at the point on the Sabine River where that river was crossed by the 32nd parallel and then by meridian north to $33^{\circ} \mathrm{N}$. While the precise location of the corner on the Sabine was not officially determined until 1841, William Darby in 1812 sited the point (known in the early nineteenth century as Darby's Corner) ${ }^{6.1}$ to his satisfaction, and for much of the period leading up to the running of the final boundary this un-surveyed location (and the un-surveyed meridian associated with it) served as the border reference point for the United States. ${ }^{6} 2$

The Sabine River-32nd parallel intersection took on official international status as the southern terminus of the border between the United States and Spain (later Mexico, and then Texas) north of the Sabine with the signing of the Adams-Onís Treaty in 1819. In this treaty it was agreed that the Louisiana-Texas border would be defined as beginning at the

River Sabine, in the Sea, continuing North, along the Western Bank of that River, to the 32d degree of Latitude; thence, by a Line due North, to the degree of Latitude where it strikes the Rio Roxo of Natchitoches, or Red River. ${ }^{6.3}$

6.1. In our discussion of the work of William Darby (and Gen. Terán), we will make use of three terms: Corner, Meridian and Line. The term "Corner" refers to that specific point where the 32nd parallel intersected the Sabine River. The term "Meridian" will be used to reference a due northsouth line extending from the "Corner" northward. The term "Line" will be used to refer to the line extending from the "Corner" to the mouth of the Sulphur Fork River. The locations of the Darby and Terán Corners and Meridians were never formally confirmed. The error between the two Lines, their corresponding meridians and the final United States-Republic of Texas border may be seen in Figure 1.

6.2. Tiller, Jim. Before the Line. Vol. I, An Annotated Atlas of International Boundaries and Republic of Texas Administrative Units Along the Sabine River-Caddo Lake Borderland, 1803-1841. Huntsville, TX: The START Group, 2010. pp. 7-16; Tiller, Jim. "Darby's Line," Handbook of Texas Online. (see URL, http://www.tshaonline.org/handbook/online/articles/nbd01). Published by the Texas State Historical Association. Darby's Meridian was located approximately 5.5 miles west of the present Louisiana-Texas border.

6.3. Bevans, Charles I. (editor). Treaties and Other International Agreements of the United States of America, 1776-1949. Vol. XI. Washington, D.C.: Government Printing Office, 1968-1976. p. 529. 


\section{Endnotes (cont.)}

7. Chiefs and Headmen of the Caddo Nation. Memorial to the President of the United States. No date. National Archives and Records Administration. Letters Received by the Office of Indian Affairs, 1824-1881. Roll 31, Caddo Agency (same as Tiller, Jim. Before the Line. Vol. II, Letters from the Red River, 1809-1842. Huntsville, TX: The START Group, 2012. Item 566); 27th Cong., 2nd sess. House Report 1035. p. 99.

8. Terán's Corner or intersecting point on the Sabine was located in Section 30, T10N, R15W, some 6 miles southeast of modern-day downtown Logansport, Louisiana. This point was approximately 7 miles southeast of the site officially determined in 1841 by the Joint Boundary Commission. For a discussion of Terán's Corner and Line, see Tiller, Jim. Before the Line. Vol. I, An Annotated Atlas of International Boundaries and Republic of Texas Administrative Units Along the Sabine River-Caddo Lake Borderland, 1803-1841. Huntsville, TX: The START Group, 2010. pp. 7-20; Tiller, Jim. “Terán’s Line,” Handbook of Texas Online (see URL, http://www.tshaonline.org/handbook/online/articles/ngt01). Published by the Texas State Historical Association.

9. Edwards, Larkin, James Schenick, John W. Edwards and Jacob Irwin. Certificate related to flooding on the Caddo Prairies. January 31, 1831. National Archives and Records Administration. Letters Received by the Office of Indian Affairs, 1824-1881. Roll 31, Caddo Agency (same as Tiller, Jim. Before the Line. Vol. II, Letters from the Red River, 1809-1842. Huntsville, TX: The START Group, 2012. Item 484).

10. For a discussion of the location of major Caddo villages in the region, see Tiller, Jim. Before the Line. Vol. III, Caddo Indians: The Final Years. Working manuscript.

11. Brooks, Jehiel. Summation to the Jury, ca. May 5, 1848 in the case of the United States vs. Jehiel Brooks, et al., 5th Circuit Court, District of Louisiana. Box 2, Folder 2, Item 1, The Brooks-Queen Family Collection. The American Catholic History Research Center and University Archives. The Catholic University of America. Washington, D.C. pp. 13-14

(see URL, http://www.aladin0.wrlc.org/gsdl/collect/brooks/brooks.shtml).

12. The United States vs. Jehiel Brooks, et al., United States Circuit Court for the Eastern District of Louisiana. Case 1459 (entry ELA121, General Cases, 1837-1911). National Archives and Records Administration, Southwest Region. Fort Worth, Texas; United States vs. Jehiel Brooks, 51 U. S. 442 (1850).

13. The general location of Terán's Line was confirmed by Brooks in his summation to the New Orleans District Court jury when he made note of an 1837 meeting held by a number of Rush Islanders whose purpose was to get the Caddo to protest the inclusion of the Island in the 1835 treaty (a part of the basis of the claim of fraud by Brooks against the United States). Brooks observed that this meeting

took place some sixteen miles west of Shreveport, which cannot be far from the Texas line: Terán's must have been near to, or a little east of Smyth's. ${ }^{13.1}$

In fact, the 1837 American survey plat map of T17N, R15W clearly shows "Smith's Field" straddling the line between Sections 7 and 8. ${ }^{13.2}$ 


\section{Endnotes (cont.)}

In addition to Brooks, three individuals testifying in the matter of the Grappe claim indicated that Terán's Line served as the boundary of Caddo lands in Louisiana. Joseph Valentin swore that the

Indians told him they had sold from the River Sabine along Terán's line to where it intercepts the first red water, and thence up. ${ }^{13.3}$

Sylvestre Poissot swore that

the Indians have told him frequently, and particularly at the meeting at Colonel Smyth's, that the country sold by them to Mr. Brooks was bounded by the line made by General Terán, and lay from where that line struck the first red water to Cypress Bayou, and thence west motioning with their hands in that direction. ${ }^{13.4}$

Manuel Laffitte indicated in testimony that

The Indians have told him what lands they sold by treaty in 1835, but not the quantity; they sold from Terán's line, where it touched Red River, out towards sunset. ${ }^{13.5}$

While Brooks, Valentin, Poissot and Laffitte were in agreement that Terán's Line served as the boundary between the Caddo lands ceded and Mexico (Texas), a close reading of the statements of Valentin, Poissot and Laffitte indicates all were in error as regards what the Caddo actually sold. Each indicated that the Caddo sold their lands from Terán's Line west. In fact, the Caddo believed they were selling all their lands to the east of the Line. One can only guess at the reason for such an error, although it very likely was related to a concerted effort on their part to establish the fact that the Caddo had never intended to cede Rush Island (in the view of the Rush Islanders, the Caddo had no claim to the Island). Brooks, in his own defense, summed up his views on this matter nicely when he noted that

some of the witnesses assert that the Caddos only intended to sell west of Terán's line, which, if that line was correct, would have been selling nothing, as all west of it would have been in Mexico. ${ }^{13.6}$

Finally, it is worth noting that even as late as 1837, pioneer settlers in the region south of Cross Lake in adjacent eastern Texas believed Terán's Line would pass near Smyth's improvement and strike the Red River somewhere south of the Sulphur Fork River. ${ }^{13.7}$

13.1. Brooks, Jehiel. Summation to the Jury, ca. May 5, 1848 in the case of the United States vs. Jehiel Brooks, et al., 5th Circuit Court, District of Louisiana. Box 2, Folder 2, Item 1, The Brooks-Queen Family Collection. The American Catholic History Research Center and University Archives. The Catholic University of America. Washington, D.C. pp. 12-13 (see URL, http://www.aladin0.wrlc. org/gsdl/collect/brooks/brooks.shtml).

13.2. United States Department of the Interior. Bureau of Land Management. Louisiana, Northwestern District. Springfield, Virginia (see also Louisiana. State Land Office, Division of Administration [Historical Documents]). See field notes and plat map for T17N, R15W.

13.3. 27th Cong., 2nd sess. House Report 1035. p. 28.

13.4. 27th Cong., 2nd sess. House Report 1035. p. 29. 


\section{Endnotes (cont.)}

13.5. 27th Cong., 2nd sess. House Report 1035. p. 34.

13.6. Brooks, Jehiel. Summation to the Jury, ca. May 5, 1848 in the case of the United States vs. Jehiel Brooks, et al., 5th Circuit Court, District of Louisiana. Box 2, Folder 2, Item 1, The Brooks-Queen Family Collection. The American Catholic History Research Center and University Archives. The Catholic University of America. Washington, D.C. p. 14 (see URL, http://www.aladin0.wrlc.org/ gsdl/collect/brooks/brooks.shtml).

13.7. Petition from Citizens of Red River County to the Congress of the Republic of Texas, March 11, 1837. Memorials and Petitions. Manuscript Collections, Archives and Information Services Division, Texas State Library and Archives Commission, Austin, Texas; Tiller, James Weeks. "The March 11, 1837 Petition to the Congress of the Republic of Texas for the Creation of a New County Called Green." Stirpes, the Quarterly Journal of the Texas State Genealogical Society. Vol. 47, No. 4 (December 2007). pp. 5-17.

14. Brooks, Jehiel. Summation to the Jury, ca. May 5, 1848 in the case of the United States vs. Jehiel Brooks, et al., 5th Circuit Court, District of Louisiana. Box 2, Folder 2, Item 1, The Brooks-Queen Family Collection. The American Catholic History Research Center and University Archives. The Catholic University of America. Washington, D.C. p. 14

(see URL, http://www.aladin0.wrlc.org/gsdl/collect/brooks/brooks.shtml).

15. Invoice of Goods and Property Delivered to the Caddo Indians, July 3-5, 1835. Box 1, Folder 4, Item 2, The Brooks-Queen Family Collection. The American Catholic History Research Center and University Archives. The Catholic University of America. Washington, D.C.

(see URL, http://www.aladin0.wrlc.org/gsdl/collect/brooks/brooks.shtml).

16. The 1,000,000-acre figure, while grossly in error, does have an interesting history. In a January 1835 letter to Lewis Cass, Secretary of War, President Andrew Jackson authorized the appointment of a commissioner to negotiate with the Caddo and indicated that the cession "will be about half millions of acres, it is supposed."16.1 In the March 25, 1835 instructions provided Brooks to negotiate with the Caddo for their lands, it was suggested that the

district of country occupied by these Indians may contain from six hundred thousand $(600,000)$ to one million $(1,000,000)$ of acres. ${ }^{16.2}$

In September 1835, just three months after the signing of the treaty, H.T. Williams, the Surveyor General of Louisiana, estimated that

If the Treaty with the Caddo Indians should be concluded and ratified there should be added [\$9000] for surveying 2,250 miles [1,440,000 acres], at \$4 per mile. ${ }^{16.3}$

By February 1836, the government estimate of the land to be surveyed had been reduced to 1,000,000 acres. ${ }^{16.4}$ As late as May 1848, long after the final boundary had been run between the United States and Texas and the area formally surveyed, Brooks (granted he had been out of the region for over a decade) indicated that, excluding the Edwards and Grappe reservations (a total of approximately 18,350 acres), the land ceded "amounts to more than a million of acres." ${ }^{16.5}$ Clearly, even in the late 1840 s, there was still a great deal of misunderstanding on the part of the treaty negotiator regarding precisely what the United States had purchased. 


\section{Endnotes (cont.)}

In more recent years, Cecile Carter (1995) placed the land ceded to the United States at approximately $1,000,000$ acres. ${ }^{16.6}$ Probably as a result of her widely read work, the 1,000,000-acre figure has now found its way onto a number of Caddo-related websites. ${ }^{16.7}$ Finally, noted Caddo scholar F. Todd Smith (1995) placed the cession figure at 590,503 acres. ${ }^{16.8}$

16.1. Jackson, Andrew. Letter to Lewis Cass, Secretary of War. January 28, 1835. National Archives and Records Administration. Letters Received by the Office of Indian Affairs, 1824-1881. Roll 31, Caddo Agency (same as Tiller, Jim. Before the Line. Vol. II, Letters from the Red River, 18091842. Huntsville, TX: The START Group, 2012. Items 565/567); 27th Cong., 2nd sess. House Report 1035. p. 100.

16.2. 27th Cong., 2nd sess. House Report 1035. p. $95{ }^{16.2 .1}$

16.2.1. The full text of the "report of Colonel Many" referred to in the foregoing may be found on pages 95 and 96 of House Report 1035. The original text may be found in National Archives and Records Administration. Letters Received by the Office of Indian Affairs, 1824-1881. Roll 31, Caddo Agency (same as Tiller, Jim. Before the Line. Vol. II, Letters from the Red River, 1809-1842. Huntsville, TX: The START Group, 2012. Item 569).

16.3. 24th Cong., 1st sess. Senate Document 3. p. 31.

16.4. 24th Cong., 2nd sess. Senate Document 3. p. 3.

16.5. Brooks, Jehiel. Summation to the Jury, ca. May 5, 1848 in the case of the United States vs. Jehiel Brooks, et al., 5th Circuit Court, District of Louisiana. Box 2, Folder 2, Item 1, The Brooks-Queen Family Collection. The American Catholic History Research Center and University Archives. The Catholic University of America. Washington, D.C. p. 9

(see URL, http://www.aladin0.wrlc.org/gsdl/collect/brooks/brooks.shtml).

16.6. Carter, Cecile Elkins. Caddo Indians: Where We Come From. Norman, OK: University of Oklahoma Press, 1995. p. 274.

16.7. See for instance, http://www.caddohistory.com/caddo indians.html

16.8. Smith, F. Todd. The Caddo Indians: Tribes at the Convergence of Empires, 1542-1854. College Station, TX: Texas A\&M Press, 1995. p. 122. Smith's estimate is taken from the work of historian G.W. McGinty. ${ }^{16.8 .1}$

16.8.1. McGinty, G.W. “Valuating the Caddo Land Cession of 1835." Louisiana Studies. Vol. II, No. 2 (Summer 1963). pp. 59-73.

17. While the typical price paid for lands at initial public sale was $\$ 1.25$ per acre or $\$ 800$ per section, it should be noted that not all of the sale price could be considered profit to the government. In addition to the initial cost of the land and promotional and administrative expenses associated with the sales, surveyors 


\section{Endnotes (cont.)}

were typically paid $\$ 4$ per mile for their work. For open land where the work included all of the lines in a township (the 4 exterior lines as well as the interior section lines) the cost (based on 84 miles) averaged \$336-a little less if one or more of the exterior lines had already been run as a result of an adjacent survey. Survey costs jumped sharply when the Red River and larger area lakes were involved as the surveyor had to run his lines along the banks of those waterbodies. ${ }^{17.1}$

17.1. See for instance the plat map for T16N, R12 and T16N, R13W which fronted the Red River. In surveying portions of approximately 22 of the township's 36 sections which lay on the east side of the river, the surveyor charged the government for some 101 miles (\$404).

18. Ward, William R.D. Original Land Grant Collection, Shelby County, Class 1, File 000158. Archives and Records Division. Texas General Land Office. Austin, Texas.

19. 49th Cong., 1st sess. House Executive Document 1, Vol. 2, Part 2. Survey of Bayou Pierre, Louisiana. Map Showing Work Accomplished in 1884 [Plate II]. The Caddo Parish levee system along the Red River was not completed until 1892. Prior to this date, lower portions of the floodplain were typically under water for a period of time each spring.

20. 27th Cong., 2nd sess. House Report 1035. p. 119. The reader is again reminded that Brooks, like most of those in the area at the time interested in such matters, believed that Darby's Line, not that of Terán, would more closely follow the final boundary, and that both would terminate on the Red River in the general vicinity of the Sulphur Fork. Compare the description of the boundary as understood by the United States (see again Gray's boundary) and the Caddo (as stated in their petition to President Jackson) with the actual text of the land cession below. Article I of the 1835 treaty defined the boundaries of the land to be sold as follows

The chiefs, head men, and warriors of the said nation, agree to cede and relinquish to the United States all their land contained in the following boundaries, to wit:

Bounded on the west by the north and south line which separates the said United States from the republic of Mexico between the Sabine and Red Rivers, wheresoever the same shall be defined and acknowledged to be by the two Governments. On the north and east by the Red River, from the point where the said north and south boundary line shall intersect the Red River, whether it be in the Territory of Arkansas or the State of Louisiana, following the meanders of the said river down to its junction with the Pascagoula Bayou. On the south by the said Pascagoula Bayou to its junction with the Bayou Pierre, by said bayou to its junction with Bayou Wallace, by said bayou and Lake Wallace to the mouth of the Cypress Bayou, thence up said bayou to the point of its intersection with the first mentioned north and south line, following the meanders of the said water-courses; but if the said Cypress Bayou be not clearly definable, so far then from a point which shall be definable by a line due west, till it intersects the said first-mentioned north and south boundary line, be the content of land within said boundaries more or less. ${ }^{20.1}$

Ultimately, the problem for the Caddo was not the point-of-intersection on the Sabine (they were in relatively close proximity to each other), but rather the point at which the final line struck the Red River.

20.1. 27th Cong., 2nd sess. House Report 1035. pp. 73-74.

21. United States Department of the Interior, Bureau of Land Management. Williams and Boyd, Articles of Agreement for Surveying R16W (Northwestern Louisiana). January 1, 1837. Springfield, Virginia. 


\section{Endnotes (cont.)}

22. United States Department of the Interior. Bureau of Land Management. Louisiana, Northwestern District. Springfield, Virginia (see also Louisiana. State Land Office, Division of Administration [Historical Documents]). See field notes and plat map for T16N, R16W.

23. For a discussion of the re-location of Caddo villages from modern-day Louisiana to Texas, see Tiller, Jim. Before the Line. Vol. III, Caddo Indians: The Final Years. Working manuscript.

24. United States Department of the Interior. Bureau of Land Management. Louisiana, Northwestern District. Springfield, Virginia (see also Louisiana. State Land Office, Division of Administration [Historical Documents]). See field notes and plat map for T17N, R16W.

25. United States Department of the Interior, Bureau of Land Management. Williams and Terrell, Articles of Agreement for Surveying R17W (Northwestern Louisiana). April 1, 1837. Springfield, Virginia.

26. United States Department of the Interior. Bureau of Land Management. Louisiana, Northwestern District. Springfield, Virginia (see also Louisiana. State Land Office, Division of Administration [Historical Documents]). See field notes and plat maps for T12N through T23N, all in R17W.

27. In 1841, the final boundary between the United States and the Republic of Texas was run. As a result of this survey, the United States returned all of R17W and the western half of the western-most tier of sections in R16W to Texas.

28. For a discussion of R17W, see Tiller, Jim. Before the Line. Vol. I, An Annotated Atlas of International Boundaries and Republic of Texas Administrative Units Along the Sabine River-Caddo Lake Borderland, 1803-1841. Huntsville, TX: The START Group, 2010. pp. 26-31. The distances presented here are measured due west from downtown Shreveport.

29. Chiefs and Headmen of the Caddo Nation. Memorial to the President of the United States. No date. National Archives and Records Administration. Letters Received by the Office of Indian Affairs, 1824-1881. Roll 31, Caddo Agency (same as Tiller, Jim. Before the Line. Vol. II, Letters from the Red River, 1809-1842. Huntsville, TX: The START Group, 2012. Item 566); 27th Cong., 2nd sess. House Report 1035. pp. 98-100.

30. Brooks, Jehiel. Letter to Judge Elbert Herring, Commissioner of Indian Affairs. October 15, 1834. National Archives and Records Administration. Letters Received by the Office of Indian Affairs, 1824-1881. Roll 31, Caddo Agency (same as Tiller, Jim. Before the Line. Vol. II, Letters from the Red River, 1809-1842. Huntsville, TX: The START Group, 2012. Item 557).

31. 27th Cong., 2nd sess. House Report 1035. pp. 117-118.

32. Chiefs and Headmen of the Caddo Nation. Memorial to the President of the United States. No date. National Archives and Records Administration. Letters Received by the Office of Indian Affairs, 1824-1881. Roll 31, Caddo Agency (same as Tiller, Jim. Before the Line. Vol. II, Letters from the Red River, 1809-1842. Huntsville, TX: The START Group, 2012. Item 566); 27th Cong., 2nd sess. House Report 1035. pp. 98-100. 


\section{Endnotes (cont.)}

33. Many, Col. James B. Letter to D. Kurtz, Acting Commissioner, Indian Affairs. January 6, 1835. National Archives and Records Administration. Letters Received by the Office of Indian Affairs, 1824-1881. Roll 31, Caddo Agency (same as Tiller, Jim. Before the Line. Vol. II, Letters from the Red River, 1809-1842. Huntsville, TX: The START Group, 2012. Item 569).

34. The border described by Col. Many in his report would have been Terán's Line.

35. Many, Col. James B. Letter to D. Kurtz, Acting Commissioner, Indian Affairs. January 6, 1835. National Archives and Records Administration. Letters Received by the Office of Indian Affairs, 1824-1881. Roll 31, Caddo Agency (same as Tiller, Jim. Before the Line. Vol. II, Letters from the Red River, 1809-1842. Huntsville, TX: The START Group, 2012. Item 569).

36. 27th Cong., 2nd sess. House Report 1035. p. 117.

37. 27th Cong., 2nd sess. House Report 1035. p. 118.

38. 27th Cong., 2nd sess. House Report 1035. p. 118.

39. 27th Cong., 2nd sess. House Report 1035. p. 120.

40. 27th Cong., 2nd sess. House Report 1035. p. 119. An explanation of the $\$ 200$ per mile figure is provided by Brooks in his summation to the District Court jury. He noted that the

Caddo cession, exclusive of reservations, amounts to more than a million of acres, which makes this only proposition of the Caddos (the 100 dollars a mile) amount to upwards of 150,000 dollars. ${ }^{40.1}$

Although erroneously based on a land sale of 1,000,000 acres and a price referred to here as $\$ 100$ per mile (and not the $\$ 200$ per mile stated in the Treaty Journal), ${ }^{40.2}$ the phrase "one hundred dollars a mile" surely referred to a price of $\$ 100$ per section (640 acres, or one square mile) of land. ${ }^{40.3}$ In indicating that the proposition of the Caddo would have resulted in an amount of $\$ 150,000$, it is clear that this figure was arrived at by dividing the 1,000,000 acres by 640 acres (a "mile" as defined by Brooks). This resulted in an estimated 1562.5 sections in the Caddo cession. At $\$ 100$ per section, the cost to the government would have been $\$ 156,250$ (or $\$ 150,000$ as rounded off by Brooks).

40.1. Brooks, Jehiel. Summation to the Jury, ca. May 5, 1848 in the case of the United States vs. Jehiel Brooks, et al., 5th Circuit Court, District of Louisiana. Box 2, Folder 2, Item 1, The Brooks-Queen Family Collection. The American Catholic History Research Center and University Archives. The Catholic University of America. Washington, D.C. p. 9

(see URL, http://www.aladin0.wrlc.org/gsdl/collect/brooks/brooks.shtml).

40.2. 27th Cong., 2nd sess. House Report 1035. pp. 118-119.

40.3. In the Caddo Treaty Journal, note is made that "we have given to Larkin Edwards, our best friend since the death of Grappe, one mile of land, to be taken wherever he may choose." By the terms of the treaty, Edwards was given 640 acres which he later sold to a syndicate which in turn used this land to establish the settlement of Shreveport. See 27th Cong., 2nd sess. House Report 1035. p. 118. 


\section{Endnotes (cont.)}

41. See for example the following, all found in National Archives and Records Administration. Letters Received by the Office of Indian Affairs, 1824-1881. Roll 31, Caddo Agency (same as Tiller, Jim. Before the Line. Vol. II, Letters from the Red River, 1809-1842. Huntsville, TX: The START Group, 2012 (see specific Item): Caddo Chiefs and Headmen. Memorial to Lewis Cass, Secretary of War. January 9, 1837 (Items 580/589); Caddo Chiefs and Headmen. Statement of July 9, 1835 appointing Jehiel Brooks their attorney for annuity purposes (Item 599); Caddo Chiefs. Memorandum of Agreement with Jehiel Brooks. July 10, 1835 (Item 600); Caddo Chiefs. Letter to Martin Van Buren, President. February 4, 1838 (Item 601); Caddo Nation of Indians. Letter to Charles A. Sewall. October 11, 1838 (Items 620/625); Caddo Chief, Headmen and Warriors. Statement Repealing 4th Article of the 1835 Treaty. January 23, 1840 (Item 629); Caddo Chief, Headmen and Warriors. Statement Regarding the Power of Attorney to Charles A. Sewall. January 23, 1840 (Item 630); Principal Caddo Chiefs. Portion of a statement, most likely related to the T.G.H. Scott power of attorney. Undated, but probably February 4, 1838 (Item 641).

42. See for example the following, all found in National Archives and Records Administration. Letters Received by the Office of Indian Affairs, 1824-1881. Roll 31, Caddo Agency (same as Tiller, Jim. Before the Line. Vol. II, Letters from the Red River, 1809-1842. Huntsville, TX: The START Group, 2012 (see specific Item): Green, John G. Letter to Gen. E.W. Ripley, Member, United States House of Representatives. December 10, 1836 (Item 586); Green, John G. Letter to Gen. E.W. Ripley, Member, United States House of Representatives. December 24, 1836 (Item 588); Green, John G. Letter to Gen. E.W. Ripley, Member, United States House of Representatives. January 20, 1837 (Item 590); Scott, Tyree G.H. Letter to Martin Van Buren, President. May 3, 1838 (Item 602); Scott, Tyree G.H. Letter to Joel R. Poinsett, Secretary of War. August 29, 1838 (Item 603); Scott, Tyree G.H. Letter to Joel R. Poinsett, Secretary of War. December 25, 1838 (Item 604); Many, Col. James B. Letter to Joel R. Poinsett, Secretary of War. April 19, 1839 (Item 621); Scott, Tyree G.H. Statement regarding the Council of Caddo Indians with H.G. Rind. January 23, 1840 (Items 631/637); Williamson, Thomas T. Letter to Ambrose H. Sevier. February 24, 1840 (Item 650).

With regard to Endnote 41 and 42, the reader is reminded of Tsauninot's June 26 speech in which he stated that Chief Tarshar

gave his consent to whatever we might agree to, and would never hereafter make any objection to its fulfillment. [That the Caddo believed the President would] deal justly with us. ${ }^{42.1}$

The Caddo, be it because they were satisfied with the dollar amount offered or they were just people of their word, do not appear to have ever raised a complaint about the price received for their lands. ${ }^{42.2}$

42.1. 27th Cong., 2nd sess. House Report 1035. p. 117.

42.2. Readers may be familiar with the September 19, 1837 memorial sent by the Caddo to the Senate of the United States in which they complained that Brooks included in the treaty land they did not claim (Rush Island).42.2.1 This memorial would have offered a prime opportunity for the Caddo to have outlined their grievances regarding the western boundary of the land sold and/or the price paid. Certainly the tribe would appear to have had a lot to complain about in September 1837. At that point, the Caddo had definitely been cheated out of most of their $\$ 10,000$ annuity due in September 1836. 42.2.2 $^{4}$ While the record is not entirely clear, it appears John G. Green was in the process of taking for his own benefit much of their 1837 annuity. ${ }^{42.2 .3}$ In 


\section{Endnotes (cont.)}

March, the tribe had been forced to abandon the Louisiana village in R16W; in April contracts had been let to survey out R17W which the Caddo well understood would result in the loss of Dehahuit's village; in May the United States completed the surveys in R16W south of Cross Lake thereby taking in tribal lands lying over 6 miles to the west of Terán's Line. By any measure, based on their understanding of the treaty, the United States appeared to be taking advantage of them. Yet there is not a single word in the 1837 memorial regarding any of these events. The memorial is instead focused entirely on adding their voice to those of the Rush Islanders who at the time were attempting to persuade the government to open an investigation into their contention that the tribe had no claim to Rush Island and that Brooks, in including it as a part of the Caddo cession, had caused a fraud to be committed against the United States.

The meeting at which the memorial was drafted was held at the house of John Smyth (see again Endnote 13). Samuel Norris (Brooks' chief Rush Island accuser and the individual whose memorial finally succeeded in initiating a Congressional investigation of the Grappe matter $)^{42.2 .4}$ organized the event, and two of the four memorial interpreters (Charles Rembin and Cesair Laffitte) offered testimony against Brooks in the Grappe matter (as did Rembin's brother Lewis Naville Rembin). Interpreter Andre Valentin was a notorious whiskey trader and father of Joseph Valentin (who also provided testimony against Brooks). ${ }^{42.2 .5}$ The identity of P. Poissot (the fourth interpreter) is unknown, although a Sylvestre Poissot testified against Brooks in the Grappe matter and it is likely that either the two were blood relatives or, more likely, the "S" of Sylvestre's name was transcribed in error-upper case "S" and "P" letters often look similar in handwritten original texts).

For those with an interest in the Grappe matter, the September 1837 memorial holds some value. Those who seek to use it to support a case against Brooks in his dealings with the Caddo should probably consider the names and motives of those in attendance, but, perhaps more importantly, the name and motives of one individual who was not present at Smyth's-Larkin Edwards, the trusted advisor and Caddo counselor.

42.2.1. 27th Cong., 2nd sess. House Report 1035. pp. 103-105.

42.2.2. For an analysis of the 1836 Caddo annuity payment, see Tiller, Jim. Before the Line. Vol. III, Caddo Indians: The Final Years. Working manuscript.

42.2.3. For an analysis of the 1837 Caddo annuity payment, see Tiller, Jim. Before the Line. Vol. III, Caddo Indians: The Final Years. Working manuscript.

42.2.4. 27th Cong., 2nd sess. House Report 1035. p. 1.

42.2.5. For the testimony of (and Brooks' thoughts regarding) Samuel Norris, Charles Rembin (and his brother Lewis Naville Rembin), Cesair Laffitte, Andre and Joseph Valentin, see 27th Cong., 2nd sess. House Report 1035 and Brooks, Jehiel. Summation to the Jury, ca. May 5, 1848 in the case of the United States vs. Jehiel Brooks, et al., 5th Circuit Court, District of Louisiana. Box 2, Folder 2, Item 1, The Brooks-Queen Family Collection. The American Catholic History Research Center and University Archives. The Catholic 


\section{Endnotes (cont.)}

University of America. Washington, D.C. (see URL, http://www.aladin0.wrlc.org/gsdl/ collect/brooks/brooks.shtml). Additional material may be found in United States vs. Jehiel Brooks, et al., United States Circuit Court for the Eastern District of Louisiana. Case 1459 (entry ELA121, General Cases, 1837-1911). National Archives and Records Administration, Southwest Region. Fort Worth, Texas.

43. 27th Cong., 2nd sess. House Report 1035. p. 28.

44. 27th Cong., 2nd sess. House Report 1035. p. 30.

45. Caddo Tribe of Oklahoma vs. the United States. Docket 226. Indian Claims Commission Decisions. Vol. 8. p. 361 (see URL, http://digital.library.okstate.edu/icc/index.html).

46. Caddo Tribe of Oklahoma vs. the United States. Docket 226. Indian Claims Commission Decisions. Vol. 8. p. 362 (see URL, http://digital.library.okstate.edu/icc/index.html).

47. Caddo Tribe of Oklahoma vs. the United States. Docket 226. Indian Claims Commission Decisions. Vol. 8. p. 362-363 (see URL, http://digital.library.okstate.edu/icc/index.html). Interestingly, on January 22, 1960, the Indian Claims Commission issued its "Opinion on Value" in Caddo Tribe of Oklahoma vs. the United States. As might be expected, the two sides held very different views of the value of the lands ceded. The plaintiffs in support of their position argued that an "1835 fair market value of the Caddo tract was \$2.50 per acre." ${ }^{47.1}$ The defendant presented testimony in which the lands purchased were valued as follows: (1) lands not subject to overflow, $\$ .40$ per acre; (2) those lands subject to overflow, $\$ .10$ per acre; and (3) watered areas, $\$ .05$ per acre-all of which the Commission believed to have been too conservative. ${ }^{47.2}$ Based on a Commission-determined total land purchase of 617,967.4 acres, the land cession was concluded to have been worth $\$ 463,475.55$ or $\$ .75$ per acre. ${ }^{47.3}$

47.1. Caddo Tribe of Oklahoma vs. the United States. Docket 226. Indian Claims Commission Decisions. Vol. 8. p. 387 (see URL, http://digital.library.okstate.edu/icc/index.html).

47.2. Caddo Tribe of Oklahoma vs. the United States. Docket 226. Indian Claims Commission Decisions. Vol. 8. p. 389 (see URL, http://digital.library.okstate.edu/icc/index.html).

47.3. Caddo Tribe of Oklahoma vs. the United States. Docket 226. Indian Claims Commission Decisions. Vol. 8. pp. 390-391 (see URL, http://digital.library.okstate.edu/icc/index.html).

48. The 38,000 acre figure suggested here was determined by calculating the acreage comprising the Red River floodplain within the Caddo cession, excluding those areas likely to have been inundated west of the line of uplands that marks the western boundary of the floodplain (cane breaks, tributary stream valleys and the like), but including the natural levees of the Red River which were probably only rarely, if ever, inundated (a total of approximately 76,000 acres), and then reducing that figure by $50 \%$. This is believed to be a relative conservative figure based on conditions in the region in 1835. 


\section{Endnotes (cont.)}

49. Between March 4, 1829 and March 29, 1836, the United States was involved in 46 separate transactions in which it was a recipient of lands ceded by various Indian tribes. ${ }^{49.1}$ In return for the 93,401,637 acres acquired, the government paid a total of $\$ 67,458,318$-a per-acre cost of $\$ .72$. In those 34 instances where no land was provided on the part of the United States, the government paid $\$ 15,919,920$ for a total of $70,027,960$ acres - a per-acre cost of $\$ .23$. These period materials indicate the Caddo sold the United States $1,000,000$ acres $^{49.2}$ at a cost of $\$ 86,800$ ( $\$ .08$ per acre). No explanation is provided as to what accounted for the extra $\$ 6,800$, although transportation costs to and from the treaty grounds and various administrative costs (i.e., military presence) associated with the treaty probably made up the bulk of the $\$ 6,800$.

The question comes, "Why did the United States not include land for a new home as a part of the land settlement with the Caddo?" The materials provided in House Document 3 clearly suggest that for the government to have done so during the 1829-1836 period would have been out of the ordinary. Of the 46 Indian land transactions during this period, in only 12 did the United States provide the ceding party both money and land in another location as part of the treaty agreement. In the other 34 instances, the tribes were only paid a specified dollar amount. It simply is not true that in paying the Caddo in cash and not providing them some quantity of land elsewhere for a new home the United States somehow treated them differently from most of tribes that ceded land to the government in the early 1830s.

Too, the reader is reminded that in 1835 the Caddo only ceded their lands lying within the bounds of the United States. At the time, it was generally known by those most familiar with the region that the Caddo villages and a significant quantity of the tribe's land actually lay within the bounds of adjacent Texas. ${ }^{49.3}$ In addition, it appears the Mexican government had offered the tribe a "grant of lands and that a number of them have gone into that country to settle." ${ }^{49.4}$ What would have been the point of providing the Caddo land in the United States when the Mexican government was clearly not opposed to their remaining in Texas?

49.1. 25th Cong., 2nd sess. House Document 3. p. 643.

49.2. The reader will note that while inflated acreage figures such as those related to the Caddo, if typical, would grossly distort the per-acre cost figures suggested, such errors were most likely associated with more recent acquisitions which had yet to be officially surveyed.

49.3. Many, Col. James B. Letter to D. Kurtz, Acting Commissioner, Indian Affairs. January 6, 1835. National Archives and Records Administration. Letters Received by the Office of Indian Affairs, 1824-1881. Roll 31, Caddo Agency (same as Tiller, Jim. Before the Line. Vol. II, Letters from the Red River, 1809-1842. Huntsville, TX: The START Group, 2012. Item 569); 27th Cong., 2nd sess. House Report 1035. pp. 95-96; see again Endnote 13, comments of Joseph Valentin, Sylvestre Poissot and Manuel Laffitte.

49.4. 27th Cong., 2nd sess. House Report 1035. pp. 33-35; Many, Col. James B. Letter to D. Kurtz, Acting Commissioner, Indian Affairs. January 6, 1835. National Archives and Records Administration. Letters Received by the Office of Indian Affairs, 1824-1881. Roll 31, Caddo Agency (same as Tiller, Jim. Before the Line. Vol. II, Letters from the Red River, 1809-1842. Huntsville, TX: The START Group, 2012. Item 569); 27th Cong., 2nd sess. House Report 1035. pp. 95-96. 